\title{
Veteriner Mikrobiyolojide Salmonella'nın Tanısında PCR ve Bakteriyolojik Yöntemlerin Meta-Analize Uygunluğunun Belirlenmesi
}

\author{
M. Uğur Nuraloğlü ${ }^{1}$, Hakan Yardımcı \\ ${ }^{1}$ Glda, Tarım ve Hayvancılık Bakanlığl, Rehberlik ve Teftiş Başkanlı $\breve{g}$, Ankara \\ ${ }^{2}$ Ankara Üniversitesi, Veteriner Fakültesi, Mikrobiyoloji Anabilim Dall, Ankara
}

Geliş Tarihi / Received: 13.10.2016, Kabul Tarihi / Accepted: 09.12.2016

\begin{abstract}
Özet: Bu çalışmada, veteriner mikrobiyolojide Salmonella'ların tanısında kullanılan bakteriyoloji ve PCR tekniklerine ait sonuçların, tutarlılık yönünden değerlendirilmesi için meta-analiz metodunun kullanılabilirliğinin belirlenmesi amaçlanmıştır. Çalışmada, belirlenen "Salmonella, veterinary, PCR, cattle, sheep, goat, pig, chicken, horse, poultry" anahtar kelimeleri ile yapılan taramada 1472 kaynağa ulaşıldı. Elektronik kütüphanenin duplikasyonları elemesinden sonra 698 literatür ayrıca mikrobiyoloji alanında iki uzman tarafından da bağımsız şekilde okunarak, hala duplikasyon olan ve İngilizce olmayan yayınlar ile kitap, kitapta bölüm ve derleme olarak yer alanların yanı sıra, Salmonella dışında çalışılmış olan makaleler ve deneysel çalışmalar elenerek kalan 601 makale, kabul ve ret kriterleri dikkate alınmak suretiyle okundu. Makaleler, çalışmaların yapıldığı hayvan türü, kullanılan numune türü, çalışmada uygulanan PCR tekniği, kültür, makalede araştırılan Salmonella türü ve istatistiki yöntem kullanılıp kullanılmaması açısından değerlendirilerek veriler çıkarıldı. Hayvan türünün, kullanılan numune türünün, kültür ve PCR yöntemlerinin çalışmalarda farklı olduğu saptandı. İncelenen ve veri çıkarılan hiçbir makalede de herhangi bir istatistiki yöntem kullanılmadığı belirlendi. Bundan dolayı, elde edilen verilerin herhangi bir tanımlayıcı istatistik yöntemiyle değerlendirilmesi mümkün olmadı. Sonuç olarak, çalışmada değerlendirilen makalelerde hayvan türünün, kullanılan numune türünün, kültür ve PCR yöntemlerinin birbirinden farklı bulunması nedeniyle, verilerin standart yapıda olmadığı saptandı. Bu heterojenlikten dolayı meta-analiz yönteminin, PCR ve bakteriyolojik yöntemlerle elde edilen sonuçların tutarlılığı yönünden karşılaştırılması amacıyla kullanılamayacağı kanısına varıldı.
\end{abstract}

Anahtar kelimeler: Kültür, meta-analiz, PCR, Salmonella

\section{Evaluation of Usage Meta-analysis for Diagnosis of Salmonella spp. Using PCR and Bacteriological Methods in Veterinary Microbiology}

\begin{abstract}
In this study, the determination of usage meta-analysis was aimed in regard to consistency of results of bacteriological culture and PCR technics for Salmonella spp. diagnosis in veterinary microbiology. For this reason, a total of 1472 sources were reached through internet by using the key words "Salmonella, veterinary, PCR, cattle, sheep, goat, pig, chicken, horse, poultry". Then, after the electronic library eliminated duplications, a total of 698 articles were obtained. The rest of the articles were reviewed again by the two experts from microbiology field independent from each other and any overlooked duplications, non-english articles, reviews, chapters in books were re-eliminated and finally a total of 601 articles were evaluated by the approval and refusal criteria to obtain utilizable data. Articles were evaluated according to the animal species, sample type, PCR technique, species of Salmonella and whether or not any given statistical methods used and related data were generated. There were differences in animal species, samples types and PCR and culture techniques. None of the articles that were examined included any relevant statistical method. Therefore, it was not possible to evaluate the obtained data by descriptive statistical methods. In conclusion, it was determined that the data were not standard because the evaluated articles in this study were different in related to animal species, sample types and materials and methods used in these articles. Because of the heterogeneity in these data, it was thought that meta-analysis could not be used for comparison PCR and bacteriological methods because of lack of consistency of the obtained results.
\end{abstract}

Key words: Culture, meta-analysis, PCR, Salmonella spp.

\section{Giriş}

Bilimsel araştırmalarda, ilgilenilen bir problem için yapılan tek bir deney araştırmacılar tarafından yeterli görülmez. Bu nedenle, merak edilen konu üzerinde birden çok deney yaparak bu çalışma sonuçlarından bilgi birikimi sağlanması bilimin temelini oluşturmaktadır [11]. Araştırıcılar, aynı konuda yapılan deneylerin tekrarlanması sonucunda, elde 
edilen sonuçların nasıl birleştirileceği problemi ile karşılaşmışlardır [10].

Meta-analiz, aynı konuda değişik yer, zaman ve merkezlerde yapılmış olan araştırma sonuçlarını niteliksel ve niceliksel olarak birleştirmede kullanılan istatistik yöntemi olarak karşımıza çıkmaktadır $[1,12,22]$. İnsan hekimliğinde uygulanan meta-analiz ile ilgili Türkiye'de ve dünyada çeşitli çalışmaların yapıldığı bildirilmiştir [1]. Veteriner hekimlik alanında ise halen dünyada uygulanmaya devam edilirken henüz Türkiye'de çok sınırlı sayıda uygulanmış istatistiksel bir metot olması dikkat çekicidir.

Herhangi bir soruna yönelik epidemiyolojik ve/veya klinik tıpta, meta-analiz çalışması yapmaya karar verilmesinin ardından öncelikle, o konuya ilişkin literatür araştırması yapılır, ardından kabul ve ret kriterleri belirlenir ve uzmanlar tarafindan fikir birliğine varılarak veriler toplanır. $\mathrm{Bu}$ adımlardan sonra, üzerinde çalışılan soruna yönelik, öncelikle bulunan çalışmaların niteliksel olarak inceleme aşaması gerçekleştirilir. Bu ara adım tamamlandıktan sonra, uygun çalışmalara niceliksel meta-analiz yöntemlerinden biri ancak uygulanabilir $[1,5,8]$. Meta-analiz; tanımlamak, tahmin etmek, sentezlemek ve ilişkili bulguları birleştirerek araştırma hakkında bir sonuca varmak için sistematik bir yaklaşımdır [19]. Meta-analizin yürütülmesine ilişkin tek bir yol mevcut değildir. Ancak bir meta-analizde mutlak olan, iyi organize edilmiş bir çalışmayı gerektirmesidir [18]. Genel olarak yapılması gereken adımlar şunlardır: Problemin Tanımlanması, Veri Toplanması ve İşlenmesi, Analiz, Raporlama.

Salmonellozis ise; Enterobacteriaceae familyasinda bulunan Salmonella genusuna ait bakteriler tarafindan oluşturulan perakut septisemi, akut ve kronik enteritis ile karakterize zoonotik bir enfeksiyondur [13]. Salmonella'lar, genellikle doku ya da vücut sıvıları ile dışkıdan hazırlanan kültürlerden mikrobiyolojik muayenelerle tespit edilebilirler [17]. Salmonella etkenlerinin konvansiyonel tekniklerle teşhisi etkenin besi yerlerinde üretilmesi, biyokimyasal ve serolojik testlere dayanmakta olup; tüm bu işlemlerin tamamlanması en azından iki hafta gibi uzun bir süre almaktadır. Etkenin saptanabilmesi amaciyla FA (Floresan Antikor), aglütinasyon, ELISA (Enzyme-Linked Immunosorbent Assay) testlerinden de yararlanılmaktadır. Ancak bu testlerin spesifiteleri aynı antijenik determinan- ta sahip olan diğer bakterilerin de saptanabilmeleri gibi nedenlerle sınırlıdır ve bu yüzden hatalı pozitif reaksiyonlar da görülebilir. Bununla birlikte, özgül genlerin amplifikasyonu temeline dayanan PCR (Polimerase Chain Reaction - Polimeraz Zincir Reaksiyonu) yoluyla teşhis serolojik testlere göre daha kesin, daha güvenilir ve daha hızlı olmaktadır $[16,17]$. Salmonella tanısında PCR'ın bakteriyolojiye göre daha etkin olduğunu saptayan araştırmalar mevcuttur [15]. Öte yandan, Salmonella tanısinda PCR'ın bakteriyolojiye göre daha etkin olduğunu belirten çalışmalar yanında bakteriyolojinin daha duyarlı olduğunu saptayan araştırmalar da bulunmaktadır [3]. PCR ve bakteriyolojinin birbirine üstünlüklerinin yanı sıra, sonuçlarının aynı şekilde rapor edildiği çalışmalar da mevcuttur [7,9].

$\mathrm{Bu}$ çalışmada, veteriner mikrobiyolojide Salmonella'ların tanısında kullanılan bakteriyoloji ve PCR tekniklerine ait sonuçların, tutarlılık yönünden değerlendirilmesi için meta-analiz metodunun kullanılabilirliğinin belirlenmesi amaçlanmıştır.

\section{Materyal ve Metot}

\section{Meta-analiz uygulanacak konu}

Bu çalışmada, "Veteriner mikrobiyolojide Salmonella'ların tanısında kullanılan bakteriyoloji ve PCR teknikleri ile elde edilen sonuçların tutarlılık yönünden incelenmesi için meta-analiz metodunun kullanılabilirliğinin saptanması" konu olarak belirlenmiştir.

\section{Konuyla ilgili literatürlerin araştırılması}

Çalışma amacıyla belirlenen konu hakkında yapılmış çalışmaların saptanması için Ankara Üniversitesi Kütüphanesi'nin üyesi olduğu veri tabanları; PubMed, Science Direct, ISI Web of Knowledge, Proquest, Summon ve Taylor and Francis kullanıld1. Bu problem için "Salmonella, veterinary, PCR, cattle, sheep, goat, pig, chicken, horse, poultry" anahtar kelimeleri değişik kombinasyonlar halinde veri tabanlarında araştırıldı $[6,14]$.

\section{Kabul ve ret kriterlerini belirlemek}

Belirlenen literatürler, kitap ve/veya bölümleri, İngilizce olmayan literatürler, derleme ve tekrarlar mikrobiyoloji alanında ayrıca iki uzman tarafindan da bağımsız şekilde değerlendirilerek ayıklandıktan sonra kalan literatürler sistematik derleme ve me- 
ta-analiz için değerlendirilmeye tabi tutuldu. $\mathrm{Bu}$ literatürler ayıklandıktan sonra, makaleler ayrıca yine bahse konu iki uzman tarafindan da bağımsız şekilde okunarak, hem kültür hem de PCR tekniğinin kullanıldığı araştırmalar, hayvanın türü, numune türü ve sayısı, PCR tekniğii, araştırılan etken türü ve kullanılan istatistiki yöntem açısından değerlendirmeye alınd $[1,6,8,14]$.

\section{Verinin toplanması}

Ayıklandıktan sonra okumaya alınan makaleler araştırmanın yapıldığ 1 hayvan türü, kullanılan numune türü ve sayısı, araştırılan etkeninin türü, istatistiki yöntem kullanılıp kullanılmaması, kullanıldı ise hangi yöntemin kullanıldığı ve çalışmanın yapıldı̆̆ 1 yıl açısından değerlendirildi ve elde edilen veriler excel programında hazırlanan çizelgeye işlendi [4].

\section{5. İstatistiksel değerlendirme}

Elde edilen verilerin değerlendirilmesi amaciyla Comprehensive Meta-Analysis (CMA) paket bilgisayar programı kullanılması planland1 [4].

\section{Bulgular}

\section{Konuyla ilgili literatürlerin araştırılması}

Çalışmada belirlenen "Salmonella, veterinary, PCR, cattle, sheep, goat, pig, chicken, horse, poultry" anahtar kelimeleri kullanılarak yapılan taramada 1472 kaynağa ulaşıldı. Elektronik kütüphanenin duplikasyonları elemesinden sonra 698 literatür kald1. Bu makalelerin de özetleri okunarak hala duplikasyon olan yayınlar (64 makale) ayıkland 1 ve bu ayıklamadan sonra İngilizce olmayan yayınlar (12 makale) ile kitap, kitapta bölüm ve derleme olarak (9 makale) yer alanların yanı sıra, Salmonella dışında çalışılmış olan makaleler (7 makale) ve deneysel çalışmalar (5 makale) elendikten sonra kalan 601 makale elde edildi.

\section{Kabul ve ret kriterleri}

Makaleler, çalışmaların yapıldığı hayvan türü, kullanılan numune türü, çalışmada uygulanan PCR tekniğgi ve makalede araştırılan Salmonella türü açısından değerlendirilerek veriler çıkarıldı.

\section{Elde edilen veriler}

Veriler ayrıntılı olarak incelendiğinde; tavuklarda yapılan ve çalışmada kullanılabilecek veriler içeren
3 makalenin 2'si piliç etinde yapılırken 1'i de piliç bağırsak örneği kloakal svab çöp örneği sürme svab civciv toz örneği kullanılarak yapılmıştır.

Numune örneğine göre verilerin detayları incelendiğinde; 2 çalışmanın buzağılarda, 1 çalışmanın sığır, 1 çalışmanın da köpeklerde yapıldığı görüldü.

Çalışmalarda kullanılan PCR tekniğine göre veriler incelendiğinde; 9 çalışmada klasik PCR tekniği kullanılırken diğer PCR yöntemlerinin kullanıldığ 1 birer çalışma olduğu, klasik PCR tekniğinin kullanıldığ çalışmaların 2'sinin tavuklarda ve piliç etinden, diğerlerinin ise psittasin kuşlarda, koyunda, et-süt ürünlerinde, buzağıda, devede, midyede ve kremada çalışılmış birer araştırma olduğu saptandi.

Salmonella spp. olarak çalışılan 11 makalenin 3 adedi tavuklarda, diğerleri deve, midye, at, psittasin kuşlar, krema, süt, yiyecek, et-süt ürünlerinde yapılan birer adet çalışmaydı. Tavuklarda yapılan 3 çalışmanın 2'si piliç etinde, 1'i de piliç bağırsak örneği kloakal svab çöp örneği sürme svab civciv toz örneği numunelerinde yapılmış bir çalışmaydı.

Bütün literatürlerin incelenmesi sonucunda; sadece tavuklarda yapılan 2 çalışmada piliç etinde kültür ve klasik PCR tekniği kullanılarak Salmonella spp. arandığı saptand.

İncelenen ve veri çıkarılan hiçbir makalede herhangi bir istatistiki yöntem kullanılmadığı belirlendi.

\section{4. İstatistiksel değerlendirme}

Elde edilen verilerin herhangi bir tanımlayıcı istatistik yöntemiyle değerlendirilmesi mümkün olmadı.

\section{Tartışma ve Sonuç}

Türkiye'de ve dünyada insan hekimliğinde sistematik derleme ve meta-analiz ile yapılan çok sayıda çalışmalar bulunmaktadır [2]. Veteriner hekimlik alanında ise dünyada yapılan araştırmalar bulunmakla beraber bu alanda Türkiye'de veteriner bilimlerde meta-analizin kullanıldığı çalışmalar sınır11 sayıdadır.

Dünyada ve Türkiye'de veteriner bilimlerde yapılan meta-analiz çalışmalarının çok az kısmının mikrobiyoloji disiplininde yapıldığ 1 görülmektedir. Domuzlarda Salmonella türlerinin tanısı için kültür ve PCR tekniklerinin tanısal doğruluğunda materyal 
ve metodolojideki farklılıkların etkisini belirlemek için sistematik inceleme, meta-analiz ve meta-regresyon yaklaşım çalışması yapmışlardır. Araştırıcılarca bu alanda yapılan ilk çalışma olduğu bildirilen çalışmada hem kültür, hem de PCR tekniklerinde önemli bir heterojenlik olduğunu bildirmişlerdir. Özellikle kültür tekniğinde zenginleştirme 1sıs1, çalışma popülasyonu, agar ve zenginleştirme yöntemlerinin çalışmalarda büyük oranda farklılık gösterdiğini, PCR tekniğinde ise örnek tipi ve çalışma büyüklüğünün farklılık gösterdiğini bildirmişlerdir. Çalışmada negatif ve pozitif kontrollerin değişkenliği, çalışmaların raporlanmasındaki yetersizlikler, örnek seçme kriterlerinin standart olmayışı gibi nedenlerle yeterli veri elde edemediklerini bildirmişler ve gida güvenliği ve halk sağlığı araştırıcılarınca araştırmaların yazımı ve yöntemlerde standartlaşmanın sağlanmasını önermişlerdir [21]. Kırım Kongo Kanamalı Ateşi virüsünün çiftlik hayvanlarında varlığ1 ve atlarda Taylorella equigenitalis 'in kültür ve PCR metotlarıyla tespitinde sonuçların tutarlı11ğının incelenmesi olarak belirledikleri iki problem için meta-analiz yöntemi uygulamak istedikleri çalışmada, her iki konuda da meta-analiz uygulanabilecek veriler elde edemediklerini belirtmişlerdir. Araştırıcılar bu durumun, hayvan türlerinin farklılığ1, makalelerde sonuçların bu türlere göre net olarak verilmemesi, etkenlerin türe göre değişmesi, alınan numunelerin, çalışma metotlarının çeşitliliği ve kullanılan istatistik yöntemlerinin çeşitliliği gibi nedenlerden kaynaklandığını, veteriner hekimliği ve hayvan sağlığını ilgilendiren çalışmalarda daha yaygın olarak sistematik derleme ve meta-analiz uygulayabilmek için yayınlanan makalelerde veri elde etmeye yarayacak bir standart oluşturularak yazım yapılmasını önerdiklerini rapor etmişlerdir [2]. Broyler piliçlerde halk sağlığı açısından önemli olan Salmonella türlerinin azaltılmasında bazı yem ve su katkı maddelerinin etkinliğini belirlemek için yaptıkları çalışmada metodolojik sağlamlık ve/veya makalelerin yazımlarının çok yetersiz olduğunu belirtmişlerdir [20].

Yapılan bu çalışmada, veteriner mikrobiyolojide Salmonella' ların laboratuvar teşhisinde klasik bakteriyolojik yöntem ve PCR tekniği ile elde edilen sonuçların tutarlılık yönünden değerlendirilmesinde meta-analiz metodunun kullanılabilirliğinin araştırılması amaçlandı. Ancak bu hipotezde de araștırıcıların bildirimlerine paralel olarak meta-analiz yapilabilecek veriler elde edilemedi. Bunun nedenleri arasında, incelenen çalışmalardaki hayvan türlerinin farklılığ 1 , makalelerde sonuçların hayvan türüne göre net olarak verilmemesi, çalışmalarda incelenen Salmonella türlerindeki çeșitlilik, alınan numunelerin çeşitliliği, gerek kültür gerekse PCR protokollerinde farkl1lıklar ve istatistiki yöntem kullanılıp kullanılmaması ve kullanılmışsa da kullanılan istatistik yöntemlerinin farklı olması sıralanabilir. Bu faktörler de sağlıklı meta-analiz yapmayı sağlayacak verilerin elde edilmesini oldukça zorlaştıran nedenlerdir.

Sonuç olarak; Farklı yer ve zamanlarda yapılmış olan çalışmalardan elde edilen dağınık bilginin bir araya getirilmesi ve yüksek kanıt düzeyinde bilgi elde etmeye olanak veren meta-analiz teknikleri, büyük bir imkan olmakla birlikte her sorunun cevabını verebilen yöntemler de değillerdir. Diğer araştırma yöntemlerinde karşılaşılabilecek çeşitli kısıtlılıklar meta-analiz çalışmalanı için de büyük sorundur. $\mathrm{Bu}$ nedenle hem meta-analiz çalışması planlarken, hem de yapılmış bir çalışmayı değerlendirirken bu kısıtlamalar unutulmamalıdır. Yapılan bilimsel çalışmaların birbiriyle benzer olması durumunda indeksli dergilerde orijinal olmadığı gerekçesi ile yayınlanamadığı, bu nedenle de incelenen konudaki yayınlarda bir homojenlik olmadığ 1 saptand1. Materyal ve metot yönünden birbirinden tamamen farklı olan bu çalışmalardan standart verilere ulaşılamadı ve okunan makalelerdeki bu heterojenlik nedeniyle meta-analizde kullanılacak veriler elde edilemedi.

Çalışmalardaki heterojenlikten kaynaklanan nedenlerle standart veriler elde etmeye uygun olmayan kültür ve PCR teknikleri gibi yöntemlerle elde edilen sonuçların tutarlı1ık yönünden karşılaştırılması amaciyla meta-analiz yönteminin kullanılamayacağı kanısına varıldı.

$\mathrm{Bu}$ sonuca göre, araştırmalarda meta-analiz yönteminin kullanılabilmesi için şunlar önerilebilir:

Meta-analiz çalışmasında ilk aşama olan hipotezin oluşturulmasıdır. Bu aşamada meta-analiz yapmaya elverişli standart verilerin elde edilebileceği doğru bir hipotez oluşturulması çok önemlidir. Hipotez oluşturulurken, araştırıcılar kabul ve ret kriterleri için uygun eşiği saptayarak heterojenlikten kaynaklanabilecek sorunları giderebilirler. Sonraki 
aşama ise, oldukça zaman alıcı bir süreç olan literatür tarama, değerlendirme ve veri elde etme aşamasıdır. Bu aşamada mümkün olduğunca fazla eş anlamlı anahtar kelime kullanmak birçok araştırmanın elde edilmesini sağlayacaktır. Makalelerde verilen bilgilerin net yazılmaması durumunda yazara ulaşarak veya eldeki veriler ile hesaplamalar yaparak veri elde etmek mümkün olsa da, bu her zaman mümkün olamamaktadır. Bu dönem, çok büyük miktarlarda verilerle uğraşmayı gerektiren bir süreç olduğu için genellikle bir kişinin tek başına üstesinden gelebileceğinden daha fazla iş yükü olması nedeniyle sağlıklı bir meta-analiz çalışmasının bir ekip tarafından gerçekleştirilmesinde büyük yarar vardır.

Ayrıca, yayınlanacak makalelerde meta-analizde kullanılabilecek verilerin elde edilmesi için makalelerin yazımında belirli standartlar konulmalidır. Yayınlanan makalelerin bu standartlara uygun olup olmadığını inceleyen, uygun olan makalelere de sistematik derleme ve meta-analiz uygulayarak, yetkili otoritelere sahada kullanılabilir kanıta dayalı sonuçlar sunabilen, veteriner mikrobiyoloji yanında diğer veteriner bilimlerini de kapsayan kurumsal bir yapı oluşturulması faydalı olacaktır.

\section{Teșekkür}

$\mathrm{Bu}$ makale, aynı isimli doktora tez çalışmasından hazırlanmış olup, buna temel teşkil eden doktora tezimin, "Gereç ve Yöntem"i gereği elde edilen literatürlerin değerlendirilerek ayıklanmasında uzman olarak emeği geçen Harran Üniversitesi Veteriner Fakültesi Mikrobiyoloji Anabilim Dalı öğretim üyesi Prof. Dr. Oktay Keskin ve Dicle Üniversitesi Veteriner Fakültesi Mikrobiyoloji Anabilim Dalı öğretim üyesi Yrd. Doç. Dr. Neval Berrin Arserim'e teşekkür ederim.

\section{Kaynaklar}

1. Akçil M, Karaağaoğlu E, (2001). Tipta Meta Analizi. Hacettepe Tip Dergisi. 32(2), 184-190.

2. Arserim NB, Keskin O, (2012). Veteriner Epidemiyoloji'de Sistematik Derleme ve Meta-analizi. Dicle Üniv Vet Fak Derg. 2(1), 37-39.

3. Carli KT, Unal CB, Caner V, Eyigor A, (2001). Detection of Salmonellae in chicken faces by a combination of tetrathionate broth enrichment, capillary PCR, andcapillary gel electrophoresis. Journal of Clinical Microbiology. 39, 1871- 1876.

4. Çarkungöz E, (2010). Meta Analizinin Veteriner Hekimlikte Uygulanması. Yüksek Lisans Tezi, Uludağ Üniversitesi Sağlık Bilimleri Enstitüsü Biyoistatistik Anabilim Dalı, Bursa.
5. Egger M, Smith GD, Phillips AN, (1997). Meta- Analysis. Principles and Procedures. British Medical Journal. 315, 1533-1537.

6. Egger M, Smith GD, Altman DG, eds., (2001). Systematic Reviews In Health Care: Meta-Analysis In Context. Second edition. BMJ Publishing Group, p.1-487.

7. Eyigor A, Carli KT, (2003). Rapid detection of Salmonella from poultry by real-time polymerase chain reaction with fluorescent hybridization probes. Avian Diseases. 47, 380-386.

8. Fisher M, Friedman SB, Strauss B, (1994). The Effects of Blinding on Acceptance of Research Papers by Peer Review. JAMA. 272(2), 143-146.

9. Gouws PA, Visser M, Brözel VS, (1998). A polymerase chain reaction procedure for the detection of Salmonella spp. within 24 hours. Journal of Food Protection. 61, 1039-1042.

10. Hedges L, Olkin I, (1985). Statistical methods for meta-analysis. Academic Press, New York. p.224-236.

11. Hunter J, Schmidt FL, Jackson GB, (1982). Meta-Analysis: Cumulating research findings across studies. Sage Publication, California. p.56-62.

12. Hunter JE, Schmidt FL, (1990). Methods of Meta-Analysis Correcting Error and Bias in Research Findings. The Publisher of Proffesional Social Science, Newbury Park, London, New Delhi.

13. İzgür M, (2006). Enterobakteri Infeksiyonlarl (Enterobacteriaceae). Aydın N, Paracıkoğlu J. eds. Veteriner Mikrobiyoloji (Bakteriyel Hastalıklar). İlke-Emek Yayınları, Ankara. p.109-127.

14. Leandro G, (2005). Meta-analysis in medical research : the handbook for the understanding and practice of meta-analysis. First published. Blackwell Publishing, Massachusetts, USA. p.1-98.

15. Oliveira SD, Santos LR, Schuch DMT, Silva AB, Salle CTP, Canal CW, (2002). Detection and identification of salmonellas from poultry-related samples by PCR. Veterinary Microbiology. 87, 25-35.

16. Ridge SE, Harkin JT, Badman RT, Mellor AM, Larsen JWA, (1995). Johne's disease in alpacas (Lama pacos) in Australia. Aust. Vet. J. 72, 150-153.

17. Rodriguez JM, (1997). Detection of pathogens by using the Polymerase Chain Reaction(PCR). Vet. Journal. 153, 287-305.

18. Shelby LB, Vaske JJ, (2008). Understanding Meta-Analysis: A Review of the Methodological Literature. Leisure Sciences. 30(2), 96-110.

19. Stroup DF, Berlin JA, Morton SC, (2000). Meta Analysis of Observational Studies in Epidemiology. JAMA. 283(15), 2008-2012.

20. Totton SC, Farrar AM, Wilkins W, Bucher O, Waddell LA, Wilhelm BJ, Mcewen SA, Rajić A, (2012). The effectiveness of selected feed and water additives for reducing Salmonella spp. of public health importance in broiler chickens: a systematic review, meta-analysis, and meta-regression approach. Prev Vet Med. 106(3-4), 197-213.

21. Wilkins W, Rajić A, Parker S, Waddell L, Sanchez J, Sargeant J, Waldner C, (2010). Examining heterogeneity in the diagnostic accuracy of culture and PCR for Salmonella spp. in swine: a systematic review/meta-regression approach. Zoonoses And Public Health. 57(1), 121-34.

22. Wolf FM, (1986). Meta-Analysis : Quantitative Methods for Research Synthesis. Series: Quantitative Applications in the Social Sciences. Sage Publications, California. 3, 7-59. 